\title{
PREVENTION OF URINARY TRACT INFECTION FOLLOWING SPINAL CORD INJURY
}

\author{
By J. W. Pearman, M.B., B.S. \\ Department of Microbiology and Spinal Injuries Unit of the Royal Perth Hospital, \\ Perth, Western Australia
}

\section{INTRODUCTION}

IMMEDIATELY following spinal cord injury there is a phase of spinal shock, during which time the bladder is paralysed and becomes overdistended unless emptied. If the bladder wall is overstretched there is initial loss of contractility followed by interstitial fibrosis within the detrusor muscle (Bradley et al., 1963, 1967; Lloyd-Davies et al., 1970). It is inevitable that the paralysed bladder must be emptied by means of a catheter until the patient develops an efficient compensatory mechanism for voiding. If infection, either recurrent or chronic, occurs as a result of catheterisation there is an additional risk of bladder wall fibrosis which in itself may contribute to loss of function (Tribe \& Silver, I969). It is now abundantly clear that careful management of the bladder during the immediate and early period after injury to the spinal cord is absolutely vital. If the bladder is severely damaged by overdistension or infection voiding will probably be impaired permanently. However, if the bladder is protected from the ravages of overdistension and infection, most patients will develop compensatory mechanisms for bladder emptying, with a residual urine which is sufficiently low to be acceptable. One this has been achieved the risk of infection is materially reduced on a long term basis.

There are two possible regimes of catheterisation, i.e. either indwelling or intermittent, both of which are associated with infection. In our experience the probability of infection with indwelling catheters is too high to be acceptable. Intermittent catheterisation also carries a considerable risk, but methods have been devised at Stoke Mandeville and in the Royal Perth Hospital Spinal Injuries Unit which make this technique satisfactory.

Intermittent catheterisation immediately following spinal cord injury was introduced by Guttmann (1949, I953, 1963). In I966 Guttmann and Frankel reviewed 476 traumatic paraplegics and tetraplegics admitted to Stoke Mandeville within the first I4 days after injury during an II year period. These patients had been managed by intermittent catheterisation using a non-touch technique. Their findings indicated that the overall incidence of urinary tract infection in paraplegics and tetraplegics assessed at the time of discharge from hospital was 37.8 per cent. However, it should be stated that a proportion of these patients developed their infections prior to being admitted to their specialist unit. Walsh (I968) found in 92 male patients and 15 female patients treated by intermittent catheterisation, at the time of their discharge from hospital, an overall percentage of infection of only 19.6 per cent.

In the Spinal Injuries Unit of the Royal Perth Hospital general measures are taken to ensure that the technique of catheterisation is of a very high standard, but this in itself does not prevent bacteria from being carried into the bladder when catheters are passed. Continuous bacteriological monitoring of the urine showed that when micro-organisms were cultured there was a tendency for colony counts to show a significant increase during the next 24 to 72 hours in most 
instances. These observations suggested that the critical phase of contamination occurred when the catheter passed up the urethra carrying urethral microorganisms into the bladder, a proportion of which were not completely flushed out when the bladder was emptied. To eradicate these residual micro-organisms it was decided to inject an antibacterial solution into the bladder immediately prior to withdrawal of the catheter, care being taken to ensure that the solution was left in the bladder after the catheter was removed. Other workers have used this method for other types of patients with a considerable degree of success (Paterson et. al., I960; Gillespie, Lennon et. al., I962; McFadyen \& Simmons, I968). However, there is no record in the literature of the method being used in patients with spinal cord injury.

Initially $60 \mathrm{ml}$. of an aqueous solution of $\mathrm{I}$ in 5000 chlorhexidine digluconate was instilled at the end of every intermittent catheterisation; unfortunately this was associated with severe haematuria in several patients. Chemical cystitis and haematuria due to the same concentration of chlorhexidine digluconate has been reported by other workers (McFadyen \& Simmons, I968). To overcome this a solution containing two bactericidal antibiotics, which were effective against most of the pathogens responsible for urinary tract infections in the Perth Spinal Injuries Unit, was substituted, namely, kanamycin and colistin. Because the rate of absorption (if any) of these drugs via the bladder mucosa was not known at the commencement of the programme, injectable preparations were used, i.e. kanamycin was preferred to neomycin.

Immediately intermittent catheterisation was dispensed with, all patients were commenced on long-term prophylaxis with methanamine mandelate (Mandelamine $^{\mathrm{R}}$ ) and a supplementary agent (usually ammonium chloride) to acidify the urine, provided these drugs could be tolerated without gastrointestinal upset.

Details of the Trial of Management Techniques for the Prevention of URINARY TRACT INFECTION DURING INTERMITTENT CATHETERISATION

\section{Outline of Bladder Management}

I. A non-touch technique of intermittent catheterisation was used.

2. A specimen of urine was obtained for culture at every catheterisation.

3. After the bladder had been drained as completely as possible, I50 mg. of kanamycin and $30 \mathrm{mg}$. of colistin in $25 \mathrm{ml}$. of sterile water were instilled, immediately prior to withdrawal of the catheter.

4. In the event of bacteriuria developing, an appropriate antibiotic was given systematically for I 4 days. While the patient was receiving the systematic antibiotic, injection of the kanamycin-colistin solution into the bladder at the end of each catheterisation was continued.

\section{Criteria for Including Patients in the Trial}

All the cases of acute traumatic paraplegia and tetraplegia admitted to the Royal Perth Hospital Spinal Injuries Unit from I February I968 to 3I December 
I969 were considered for inclusion in the trial. The only patients who were excluded were those who had very incomplete damage to the spinal cord and only required to be catheterised for five days or less because their bladder involvement was minimal. During the 23 months a total of 40 acute traumatic patients were admitted to the Unit. Four of these were excluded from the trial because they needed catheterisation for only five days or less; the remaining 36 patients were included in the trial.

\section{Definition of Period of Intermittent Catheterisation}

It was considered that intermittent catheterisation was being performed if a patient required catheterisation once every 24 hours or at more frequent intervals, i.e. every six hours. If catheterisation was performed on alternate days or at longer intervals it was considered that catheters were being passed for the purpose of checking the residual urine and not because the patient was still dependent on them for adequate bladder emptying.

\section{TABLE I}

Criteria for the Diagnosis of Significant Bacteriuria

Colony count $>$ Iooo per ml. with the same species of micro-organism in 3 consecutive specimens if catheters passed 6 or 8 hourly

OR

in 2 consecutive specimens if catheterised 12 hourly

Colony count $>$ I0,000 per $\mathrm{ml}$. in one specimen if catheter passed daily

\section{Criteria for the Diagnosis of Significant Bacteriuria}

It is generally recognised that the symptoms and signs of bacteriuria are often absent or slight. In view of the lack of reliability of the warning symptoms and signs, the true incidence of bacteriuria can only be determined by continuous bacteriological monitoring of the urine. The strict bacteriological criteria for the diagnosis of significant bacteriuria, shown in Table I, have been adhered to throughout the investigation. A specimen of urine was obtained at every catheterisation and cultured. It is realised that bacteriuria may not be synonymous with infection, i.e. damage to the bladder epithelium with reactive inflammation. However, patients with bacteriuria associated with catheterisation are in a 'high risk situation' and are likely to progress to frank infection.

\section{Criteria for Separate Episodes of Significant Bacteriuria}

A single episode of significant bacteriuria was usually represented by more than one positive culture being obtained; it referred to a series of consecutive positive cultures with the same species of micro-organism being present for several days, until eliminated by an appropriate antibiotic. If a relapse occurred within I 4 days of ceasing the antibiotic, i.e. the same micro-organism was isolated again, it was considered to be a recurrence of the original episode. However, if significant bacteriuria occurred more than I4 days after cessation of treatment, this was regarded as a new event. 


\section{RESULTS}

INCIDENCE OF SIGNIFICANT BACTERIURIA DURING INTERMITTENT CATHETERISATION Male Patients

Sixteen of the 27 male patients did not have any episodes of significant bacteriuria during the period of intermittent catheterisation. Seven patients had one episode each, three patients had two and one patient had three episodes, giving a total of 16 episodes of bacteriuria in the male group (see Table II).

TABLE II-Mean Incidence of Significant Bacteriuria in 27 Male Patients during Intermittent Catheterisation

\begin{tabular}{|c|c|c|}
\hline Number of patients & $\begin{array}{c}\text { Episodes of significant } \\
\text { bacteriuria per patient }\end{array}$ & $\begin{array}{c}\text { Summation of episodes of } \\
\text { significant bacteriuria }\end{array}$ \\
\hline I6 & Nil & Nil \\
7 & I & 7 \\
3 & 2 & 6 \\
I & 3 & 3 \\
\hline Total: 27 & & I6 \\
\hline
\end{tabular}

Number of catheterisations: $\quad=3036$

Number of episodes of significant bacteriuria: $=$ I6

Mean incidence of significant bacteriuria: $=\mathrm{I} 6$

$=\mathrm{I}$ per $\mathrm{I} 90$ catheterisations or $0.5 \%$

TABLE III-Mean Incidence of Significant Bacteriuria in 9 Female Patients during Intermittent Catheterisation

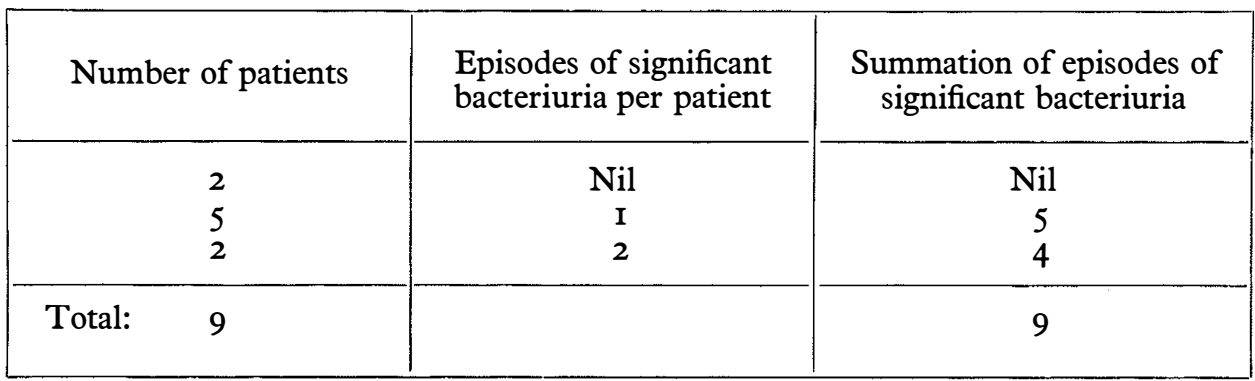

Number of catheterisations $\quad=1547$

Number of episodes of significant bacteriuria: $=9$

Mean incidence of significant bacteriuria: $=\begin{array}{r}9 \\ \hline 547\end{array}$

$=\mathrm{I}$ per $\mathrm{I} 72$ catheterisations or $0.6 \%$ 
A total of 3036 catheterisations were performed on the 27 males, during which time a total of 16 episodes of significant bacteriuria occurred. The mean incidence of significant bacteriuria in males was I per 190 catheterisations, i.e. on average 0.5 per cent. of catheterisations resulted in an episode of significant bacteriuria (see Table II.)

\section{Female Patients}

Two of the nine female patients did not have any episodes of bacteriuria during the period of intermittent catheterisation. Five patients had one episode each and two patients had two, resulting in a total of nine episodes of bacteriuria in the female group (see Table III).

A total of I 547 catheterisations were carried out on the nine females, resulting in nine episodes of bacteriuria. The mean incidence of significant bacteriuria in females was I per I 72 catheterisations, i.e. on average 0.6 per cent. of catheterisations resulted in an episode of bacteriuria (see Table III).

\section{Micro-ORganisms ResPonsible FOR Significant BaCteriURIa DURING INTERMITTENT CATHETERISATION}

\section{Male Patients}

Two facts emerged very clearly when the micro-organisms cultured from male patients were studied. Firstly, ten of the I6 episodes were due to organisms which are not usually associated with infections of the normal bladder. Staphylococcus albus was recovered in six episodes and Candida albicans in four; the overall incidence of these two organisms being more than half the total number of isolates. Secondly, when the antibiotic sensitivities of the twelve bacterial strains isolated were checked it was found that only two were sensitive to the colistin component of the kanamycin-colistin solution used routinely for bladder instillation. The remaining ten were resistant to both kanamycin and colistin (see Table IV).

\section{Female Patients}

In the case of female patients the majority of organisms cultured from urine were also unusual. Five of the nine episodes were due to Candida albicans and, without exception, all of the four bacterial strains isolated were resistant to both components of the kanamycin-colistin solution (Table V).

\section{BACTERIOLOGICAL ASSESSMENT OF URINARY TRACT AT DISCHARGE FROM HOSPITAL}

Thirty patients (23 males and seven females) were discharged from hospital catheter-free, with low residual urines and without bacteriuria (9I per cent. of those discharged). In addition, two female tetraplegics were discharged with indwelling catheters and infected urine and one male patient had an ileal conduit diversion performed. Three male patients died in hospital; two tetraplegics (aged 70 and 86 years) from bronchopneumonia and one paraplegic from pulmonary embolism. Had these three patients survived it is probable they would have been discharged free from urinary tract infection, as there was no evidence of bacteriuria at the time of death. 
TABLE IV-Micro-organisms Responsible for Significant Bacteriuria in Male Patients during Intermittent Catheterisation

\begin{tabular}{|c|c|c|c|}
\hline \multirow[b]{2}{*}{ Micro-organism } & \multirow{2}{*}{$\begin{array}{c}\text { Number } \\
\text { of episodes } \\
\text { of significant } \\
\text { bacteriuria }\end{array}$} & \multicolumn{2}{|c|}{ Antibiotic sensitivities } \\
\hline & & $\begin{array}{l}\text { Resistant to kana- } \\
\text { mycin, sensitive } \\
\text { to colistin }\end{array}$ & $\begin{array}{l}\text { Resistant to both } \\
\text { kanamycin and } \\
\text { colistin }\end{array}$ \\
\hline Staph. albus & 6 & - & 6 \\
\hline Candida albicans & 4 & - & $\begin{array}{l}4 \\
\text { (as predicted) }\end{array}$ \\
\hline Staph. aureus & 2 & 一 & 2 \\
\hline Klebsiella species & I & I & - \\
\hline Proteus mirabilis & I & - & I \\
\hline Bacterium anitratum & I & I & - \\
\hline Providence B & I & 一 & I \\
\hline Total: & I6 & 2 & I4 \\
\hline
\end{tabular}

TABLE V-Micro-organisms Responsible for Significant Bacteriuria in Female Patients during Intermittent Catheterisation

\begin{tabular}{|l|c|c|}
\hline Micro-organism & $\begin{array}{c}\text { Number of episodes of } \\
\text { significant bacteriuria }\end{array}$ & $\begin{array}{c}\text { Antibiotic sensitivities } \\
\text { resistant to both } \\
\text { kanamycin and colistin }\end{array}$ \\
\hline Candida albicans & 5 & 5 \\
Staph. aureus & 2 & $\begin{array}{c}5 \\
\text { Staph. albus } \\
\text { Strep. faecalis }\end{array}$ \\
\hline \multicolumn{1}{|c|}{ Total: } & I & I \\
I & 9 & 9 \\
\hline
\end{tabular}

\section{BACTERIOLOGICAL ASSESSMENT OF URINARY TRACT AT FOLLOW-UP}

The period of the trial covered patients admitted between I February 1968 and 3I December 1969; the last patients admitted during 1969 were discharged not later than 28 August 1970. The length of time patients have been followed up has varied depending upon their date of discharge. At the time of writing this report the shortest period was six months and the longest 34 months. 


\section{(i) Catheter-free Patients}

Of the 30 patients who were discharged catheter-free and without bacteriuria, 26 have been available for regular follow-up. Twenty-one of these have not had any episodes of significant bacteriuria. Two males have each had two episodes and another two males and one female have each had a single episode. The seven episodes of bacteriuria which occurred in these five patients were due to Klebsiella species (two episodes), Pseudomonas aeruginosa, Pseudomonas species, Enterobacter species, Staph. aureus and Candida albicans. None of these patients had bacteria in their urine when last seen.

\section{(ii) Patients with Indwelling Urethral Catheters at Discharge}

One of the female tetraplegics who left hospital with an indwelling catheter became catheter-free after discharge. Subsequent to this, short courses of sensitivity-specific antibiotics were given, when appropriate, for three urinary tract infections. Since her last infection was eliminated (13 months ago) her urine has remained sterile. The other female tetraplegic retained her indwelling catheter and suffered recurrent infections despite antibiotic treatment. This patient, who was very difficult to manage, partly due to gross mental impairment, died from chronic pyelonephritis twelve and a half months after leaving hospital.

\section{(iii) Patient with Ileal Conduit Diversion}

This patient has remained well up to the present time, although specimens of urine obtained from his ileal conduit at regular intervals usually grow Proteus species.

In summary, of the 33 patients discharged, one has died, one has an ileal conduit diversion and four have left Western Australia and are not available for follow-up. The remaining 27 are without catheters, have residual urines which are satisfactorily low and are free from bacteriuria.

\section{DISCUSSION}

The results of this trial indicate that by avoidance of the two major factors causing bladder damage, namely overdistension and infection, a very high percentage of patients with spinal cord injury can be expected to develop adequate compensatory bladder functions. In a proportion of cases surgical intervention in the form of transurethral resection of the bladder neck, with or without division of the external urethral sphincter, will be necessary to reduce the resistance to urinary outflow. However, if the bladder wall has been permanently damaged by overdistension and infection, so that it is incapable of contracting effectively, such surgical measures are unlikely to lead to satisfactory bladder emptying.

The instillation of antibiotics into the bladder, immediately prior to withdrawal of a catheter, ensures highly effective antibacterial action at the time when this is most needed, i.e. when the risk of catheter-induced bacteriuria is greatest. The topical use of antibiotics in the bladder during intermittent catheterisation provides good prophylaxis without the disadvantages associated with continuous use of broad-spectrum antibiotics systematically, e.g. toxic risks, general disturbances of body flora and superinfection. 
Candida albicans and Staph. albus were most commonly responsible for the significant colony counts which occurred occasionally in both males and females during the period of catheterisation (see Tables IV and V). In normal individuals cystitis associated with Candida albicans and Staph. albus is uncommon. However, the appearance of numerous leucocytes and erythrocytes in the urine of those patients who had significant counts of Candida albicans and Staph. albus led to the belief that these patients did, in fact, have cystitis. It is interesting to note that Candida albicans was not isolated from the urine of any patient from the time of cessation of intermittent catheterisation until discharge from hospital. It was also observed that Staph. albus was only responsible for cystitis on one occasion after intermittent catheterisation had ceased.

Candida albicans is intrinsically resistant to both kanamycin and colistin. It is also noteworthy that all the Staph. albus isolates recovered during intermittent catheterisation were likewise resistant to both antibiotics (see Tables IV and V). There are at least two possible explanations why these organisms were found most frequently. The first may be that as the catheter was withdrawn after instillation of antibiotic a small quantity of the solution followed the tip of the catheter down the urethra thereby eliminating the normal bacterial flora in the distal urethra, thus allowing overgrowth of Candida albicans and/or resistant Staph. albus. The passage of catheters subsequently might be expected to carry an exceptionally high inoculum of urethral yeasts and staphylococci into the bladder and so increase the risk of bacteriuria due to these organisms. The second possibility is that the effective antibiosis achieved by the kanamycin and colistin in the bladder eliminated the majority of urethral organisms which might have been introduced by the catheter on a random basis. This could have allowed any antibiotic-insensitive yeast cells and/or staphylococci to proliferate freely in urine without inhibition and overgrowth by competing 'conventional' urinary tract pathogens. This idea is supported by evidence which shows that the multiplication of candida is inhibited by Gram-negative bacilli (Paine, I958). Paine (1958) also showed that Gram-positive cocci were not as effective as Gram-negative bacilli in inhibiting candida growth. This association was apparently confirmed during the trial reported here since Staph. albus was cultured at the same time as Candida albicans on four of the nine occasions when significant counts of the yeast were obtained during intermittent catheterisations. It is also possible that the growth of Staph. albus may be inhibited by competing Gram-negative bacilli and that these cocci will have a greater opportunity for bladder colonisation in their absence.

It might be considered advantageous to add amphoteracin $B$ to the kanamycin-colistin solution on a routine basis in order to prevent cystitis associated with yeasts. This has not been done to date because amphoteracin B is unstable in aqueous solution and does not store well in this form. Rather than attempt prophylaxis in all patients, it has been found that the infrequent episodes of infection with yeasts are readily eliminated by a single I2-hour irrigation of the bladder with a solution of amphoteracin B in conjunction with alkalinisation of the urine for one week.

\section{SUMMARY}

Immediately following spinal cord injury there is a phase of spinal shock during which time the bladder is paralysed and becomes overdistended unless 
emptied by catheterisation. If the bladder wall is overstretched there is initial loss of contractility, followed by interstitial fibrosis within the detrusor muscle. However, if overdistension and infection are avoided during the immediate and early period after injury to the spinal cord, most patients develop satisfactory compensatory mechanisms of bladder emptying.

There are two possible regimes of catheterisation, either indwelling or intermittent, both of which are associated with infection. The probability of infection with indwelling catheters is too high to be acceptable. Intermittent catheterisation also carried a considerable risk, but ways have been devised which make this method satisfactory. A trial of management techniques for the prevention and control of urinary tract infection during intermittent catheterisation was conducted on 36 acute traumatic paraplegics and tetraplegics admitted to the Royal Perth Hospital Spinal Injuries Unit during 23 consecutive months. Precautions were taken to ensure that the technique of catheterisation was of a very high standard, but this in itself did not prevent urethral bacteria from being carried into the bladder. To eradicate these micro-organisms, two bactericidal antibiotics (kanamycin and colistin) were injected into the bladder via the catheter immediately prior to withdrawal.

During the acute phase of management a total of 3036 catheterisations were performed on 27 male patients and in this time 16 episodes of significant bacteriuria occurred. The incidence of significant bacteriuria in the male patients was I per I90 catheterisations ( 0.5 per cent.). A total of I 547 catheterisations were carried out on nine female patients, resulting in nine episodes of significant bacteriuria. The incidence of significant bacteriuria in the female patients was I per I 72 catheterisations ( 0.6 per cent.).

Ninety-one per cent. of patients discharged were catheter-free with low residual urines and without bacteriuria and have generally remained so during follow-up.

Acknowledgments. I am pleased to thank Dr. G. M. Bedbrook, Director of the Spinal Injuries Unit at Royal Perth Hospital, and Dr. E. J. England, Consultant Urologist, for having made facilities available and for encouragement. I am also indebted to Dr. E. R. J. Pavillard, Head of the Department of Microbiology, for advice and much helpful discussion. The untiring co-operation and attention to detail on the part of all the nursing staff in the spinal Injuries Unit is deeply appreciated, in particular the help of Sister L. A. Cox. I also wish to thank Mrs. C. A. Groessler for excellent technical assistance. Generous financial help for technical assistance from William R. Warner \& Co. (Australia) Pty. Ltd. is gratefully acknowledged.

\section{RÉSUMÉ}

Pendant la phase aiguë du traitement, un total de 3036 sondages a été effectué chez 27 hommes, et au cours de cette période, I6 épisodes de bactériurie ont été relevés soit I pour 190 sondages $(0.5$ per cent.).

I 547 sondages ont été effectués chez 9 femmes; 9 épisodes de bactériurie ont été relevés. L'incidence de bactériurie chez les femmes a été de I pour I 72 sondages $(0.6$ per cent.). 9I per cent. des malades, à la sortie, étaient sans sonde avec des résidus urinaires bas, sans bactériurie et le sont demeurés par la suite.

\section{ZUSAMMENFASSUNG}

Bei 3036 intermittierenden Katheterisierungen an 27 männlichen Patienten im akuten Stadium von Querschnittslähmungen traten I6 Episoden bakterieller Infektion auf, ein Prozentsatz I : I90 Katheterisierungen (0.5 per cent.). I547 Katheterisierungen wurden 
an 9 weiblichen Patienten ausgeführt, resultierend in 9 Episoden von bakterieller Infektion, ein Prozentsatz I in $\mathbf{I} 72$ ( 0.6 per cent.).

9I per cent. entlassenen Patienten waren frei vom Katheter und ohne Infektion und wurden im allgemeinen bei der Nachuntersuchung so gefunden.

\section{REFERENCES}

Bradley, W. E., Chou, S. N. \& French, L. A. (I963). Fournal of Neurosurgery, 20, 953.

Bradley, W. E., Chou, S. \& Markland, C. (1967). The Neurogenic Bladder, edited by S. Boyarsky, p. I39. Baltimore: The Williams \& Wilkins Company.

Gillespie, W. A., Lennon, G. G., Linton, K. B. \& Slade, N. (I962). British Medical fournal, 2, 13.

Guttmann, L. (1949). British Surgical Practice, 6, 445. London: Butterworth \& Co. (Publishers), Ltd.

Guttmann, L. (1953). History of the Second World War, United Kingdom Medical Series, Vol. Surgery, edited by Cope, Z., p. 422. London: Her Majesty's Stationery Office. Guttmann, L. (1963). Proc. Symposium Roy. Coll. Surg. Edinb., edited by P. Harris, p. 8o. Edinburgh.

Guttmann, L. \& Frankel, H. (I966). Paraplegia, 4, 63.

Lloyd-Davies, R. W., Clark, A. E., Prout, W. G., Shuttleworth, K. E. D. \& Tighe, J. R. (1970). Ivest. Urol., 8, I45.

McFadyen, I. R. I Simmons, S. C. (I968). F. Obstet. Gynaec. Brit. Cwlth., 75, 87I.

PaIne, T. F. Jr. (I958). Antibiotics and Chemotherapy, 8, 273.

Paterson, M. L., Barr, W. \& MacDonald, S. (1960). F. Obstet. Gynaec. Brit. Emp., 67, 394.

Tribe, C. R. \& Silver, J. R. (I969). London: Pitman Medical Publishing Company, Ltd. Walsh, J. J. (I968). Paraplegia, 6, 74.

\section{ADDENDUM}

Full details of the principles and methods of urological management used at the Royal Perth Hospital Spinal Injuries Unit and the results of this trial have been prepared in the form of a monograph which will be published later in the year. 